\title{
Qualification of Contractor Towards Construction Project in the City of Banjarmasin, Indonesia
}

\author{
Aldhika Kurniawan \\ Postgraduate of Civil Engineering, Lambung Mangkurat University, J1. Brigjen H. Hasan Basri, Pangeran, Banjarmasin Utara, \\ Banjarmasin, Kalimantan Selatan 70123, Indonesia
}

Corresponding Author Email: 1620828310006@mhs.ulm.ac.id

https://doi.org/10.18280/ti-ijes.650107

Received: 10 September 2020

Accepted: 8 January 2021

\section{Keywords:}

small business qualification, project performance, person in-charge of business agency $(P J B U)$

\begin{abstract}
This study identified the correlation between small contractor qualification and work performance of the contractor in the city of Banjarmasin. This study used the perspective of descriptive quantitative for social research. The data were collected through questionnaires distributed to contractors who worked in Banjarmasin Public Works and Spatial Planning Office (PUPR) as an agency who exploited contractor service. The analysis was conducted through product moment in Spearman's rank model. This study has resulted that the conspicuous performance factor was fulfillment of work (job) function and scope of work that are similar to the documents of project's contract. Meanwhile, the correlation of small contractor qualification and work performance of project construction in Banjarmasin was influenced by Person in-charge of Business Agency (PJBU).
\end{abstract}

\section{INTRODUCTION}

Banjarmasin as the capital city of South Kalimantan province is a city that is quite closed to the islands of Java and Sulawesi. It has a wide-open access for migrants outside of Kalimantan. Moreover, the arrival of migrants in Banjarmasin has influenced the number of construction, such as housing and business building [1], so that the number of constructions invite many contractor to sustain in this evidence. In terms of quantity, the number of construction service contractors developing in Banjarmasin is actually quite good. Yet, these contractors are still on a small scale. In terms of working implementation, local contractors do not solely rely on local labor. It is not uncommon for a number of workers to come from outside the island (e.g. The Javanese) to carry out construction service project in Banjarmasin.

The regulation of the National Construction Services Development Agency (LPJKN) Number 03 of 2017 concerning Certification and Registration of Construction Implementation Service Businesses for contractors for determining sub-qualification and construction organizers assessed some items, namely company's performance, stipulation of project completion time, the efficiency of utilization of personnel resources, capital and technology in operation of construction services.

One of the ways that the government, especially in the field of construction services carried out is filtering contractors themselves. A study used system analysis called as Analytical Hierarchy Process (AHP) to filter contractors for construction service [2]. Business agencies engaged in construction services are required to have a Business Agency Certificate (SBU) that is issued by the Construction Services Development Agency (LPJK), so that contractors will have a strong and credible legality in doing business in the construction service sector.
This study analyzed the relationship between small qualification of contractor and measuring the performance of contractors in Banjarmasin, Indonesia. This study is expected to be beneficial as a reference for project owners and contractors to improve job performance through increasing the qualification capabilities of contractors in construction project. In addition, this study can be used as a reference for construction service businesses in Banjarmasin as to improve work performance in order to compete with outside contractors.

\section{MATERIALS AND METHOD}

This study was using a descriptive quantitative paradigm for social research. This model of paradigm was intended to explain a phenomena quantitatively through numerical data [3].

The primary data collection was carried out through questionnaires and interview. The first questionnaire was given to the contractor. The contractor being studied was limited only to the Small Business Qualification contractor who handled the project at Banjarmasin City Public Works and Spatial Planning Agency in the budget year of 2016. The data were collected to identify the qualification of contractors which worked on construction service with a qualification of business enterprise based on the Regulation of Construction Services Development Agency (LPJK) Number 03 of 2017.

Primary data was obtained from a survey by distributing questionnaires that were filled in using the perceptions of predetermined respondents, namely the contractors who handled project activities at Banjarmasin Public Works and Spatial Planning Office (PUPR) in 2016/2017 with a total of 48 business agencies. The questionnaires were then distributed to the Project Directors who handled project activities at the PUPR Office of Banjarmasin City with a total of 29 
respondents (see Table 1).

The second questionnaire was given to the Project Directors to obtain answers. In addition, interview was conducted on contractors and project owners to get answers about qualification and appraisal data for a project.

Table 1. Respondents of the second questionnaire

\begin{tabular}{ccc}
\hline No. & Field of Respondents & Amount \\
\hline 1. & Field of Road and Public Street Lighting (PJU) & 4 \\
2. & Field of Bridge & 3 \\
3. & Field of River & 4 \\
4. & Field of Drainage & 5 \\
5. & Field of Housing and Construction Service & 6 \\
6. & Field of Spatial Planning & 5 \\
7. & Consultant Supervisor & 2 \\
\hline & Total & 29 \\
\hline
\end{tabular}

To complement and support primary data, this study involved secondary data that consisted of:

2.1 The Construction Work Activity Data at the PUPR Banjarmasin City Office;

2.2 The data in the Construction Services Development Institute for South Kalimantan Province; and

2.3 The data of Business Agency Association.

The sample being studied was the contractor who handled construction projects at Banjarmasin City Public Works and Spatial Planning Agency with Small Business Qualifications, $\mathrm{K} 1, \mathrm{~K} 2$ and K3 sub-qualifications. Small project construction also has a significant role in any industrial sector, includes manufacturing facilities [4]. In this study, the population of small qualified contractor companies can be seen in Table 2 .

Table 2. Data of small contractors qualification in 2017, Banjarmasin

\begin{tabular}{cccc}
\hline \multirow{2}{*}{ Association } & \multicolumn{3}{c}{ Sub-Qualification } \\
\cline { 2 - 3 } & $\mathrm{K} 1$ & $\mathrm{~K} 2$ & $\mathrm{~K} 3$ \\
\hline Askumindo & 1 & & \\
Askonas & 3 & & \\
Aspekindo & 3 & 2 & 2 \\
Akaindo & 1 & & \\
Gapensi & 4 & 10 & 15 \\
Gapeknas & 3 & 1 & \\
Gapeksindo & & 1 & 1 \\
Gapkaindo & 1 & & \\
\hline Total & 16 & 14 & 18 \\
\hline
\end{tabular}

In addition, the research variables were categorized into 2 groups, namely independent $(\mathrm{X})$ as an indicator of qualification, while dependent variable $(\mathrm{Y})$ as job performance that became an indicator of job performance (Y) which consisted of product and service (see Table 3 and Table 4).

Table 3. Average of satisfaction

\begin{tabular}{cc}
\hline Range of Value & Level of Satisfaction \\
\hline $1-1.79$ & Very Dissatisfied \\
$1.8-2.59$ & Dissatisfied \\
$2.6-3.39$ & Quite Satisfied \\
$3.4-4.91$ & Satisfied \\
$4.2-5$ & Very Satisfied \\
\hline
\end{tabular}

The scale used in this study was the Likert scale that was used to describe and assess the level of respondents' satisfaction with some categories of score, namely "very dissatisfied (score 1)", "dissatisfied (score 2)", "quite satisfied (score 3)", "satisfied. (score 4)", and "very satisfied (score 5)". Meanwhile, to determine the average satisfaction, this study used the theory of Kaplan and Norton [5].

Kaplan \& Norton published a "balanced scorecard" in a series of scientific articles and books. Since the introduction of the original concept, the balanced scorecard (BSC) has become fertile ground for development and research. The balanced scorecard helps an organization to face two fundamental problems, namely measuring organizational performance effectively and implementing strategies successfully [6].

\section{RESULTS}

\subsection{Analysis of contractor qualification}

In the perspective of legal aspect, a small qualified contractor was to handle a project at Banjarmasin City Public Works and Spatial Planning Agency, and have followed the requirements set by the employer. The categories of administrative research that was carried out were having a construction service business license and having competencies indicated that are proven by a Business Agency Certificate (SBU). This certificate is signified as a legal approval on competency and working skill of employees in a construction service agency [7].

A research on personnel aspect has obtained that the workforce in a small qualified construction service company has met the requirements with sufficient skilled and expert workforce shown by a Certificate of Skills and Expertise to handle project at the Department of Public Works and Spatial Planning in Banjarmasin [7]. In addition, throughout the project, the company employed regular (daily) and part-time labor that were not parts of the company. As for the technical personnel, it was easier for construction service companies that had a workforce with a technical background to understand some technical specifications, work description progress and process, and formulating work progress reports.

Apart from personnel aspect, a research on financial aspect has shown that the construction service companies with small qualifications already have the required level of capital capability at the Department of Public Works and Spatial Planning in Banjarmasin. Meanwhile, a research on experience aspect has also showed that contractors with minor qualifications to get a job were still highly dependent on government projects [8], especially Regional Government of Banjarmasin whose projects are highly dependent on the financial capacity of the region. In term of work location, the contractors positioned their jobs (projects) in Banjarmasin City and generally in South Kalimantan province.

Finally, the research on equipment aspect has resulted that it was obtained by small qualified contractors that handled some projects at the Department of Public Works and Spatial Planning for Banjarmasin city. The contractors exploited more of their own tools in carrying out construction project, so that it was greatly helpful to accelerate construction project with low risk, simple technology, and low cost. A study recommends that the construction equipment should be based on the condition in the field and compulsory be hold and operated by a competent person [9]. 


\subsection{Analysis of factors affecting contractor's work performance}

In this part of the study, mode value was used as a reference to determine the factors that were considered influencing work performance to produce a description of the current conditions of factors that affected work performance in the PUPR Office in Banjarmasin.

In the Likert scale, the use of mean value was to obtain a qualitative description of the performance of construction companies. After processing the validity and reliability, then the data were proceed with a test to obtain mean value (see Table 4).

Table 4. Descriptive analysis

\begin{tabular}{|c|c|c|c|c|c|}
\hline & $\mathrm{N}$ & Minimum & Maximum & Mean & Std. Deviation \\
\hline item 1 & 29 & 3.00 & 4.00 & 3.7000 & .50000 \\
\hline item 2 & 29 & 3.00 & 4.00 & 3.6800 & .50000 \\
\hline item 3 & 29 & 3.00 & 4.00 & 3.4800 & .50990 \\
\hline item 4 & 29 & 3.00 & 4.00 & 3.6000 & .50000 \\
\hline item 5 & 29 & 3.00 & 4.00 & 3.5800 & .47610 \\
\hline item 6 & 29 & 2.00 & 4.00 & 2.8400 & .50662 \\
\hline item 7 & 29 & 2.00 & 4.00 & 2.8000 & .50000 \\
\hline item 8 & 29 & 3.00 & 4.00 & 3.5000 & .47610 \\
\hline item 9 & 29 & 3.00 & 4.00 & 3.4800 & .50990 \\
\hline item 10 & 29 & 3.00 & 4.00 & 3.3200 & .47610 \\
\hline item 11 & 29 & 3.00 & 4.00 & 3.3600 & .48990 \\
\hline item 12 & 29 & 3.00 & 4.00 & 3.5200 & .50990 \\
\hline item 13 & 29 & 3.00 & 4.00 & 3.5200 & .50990 \\
\hline item 14 & 29 & 2.00 & 4.00 & 2.7200 & .50662 \\
\hline item 15 & 29 & 2.00 & 4.00 & 2.8000 & .50990 \\
\hline item 16 & 29 & 3.00 & 4.00 & 3.4400 & .50662 \\
\hline item 17 & 29 & 2.00 & 4.00 & 3.5200 & .58595 \\
\hline item 18 & 29 & 3.00 & 4.00 & 3.5600 & .50662 \\
\hline item 19 & 29 & 3.00 & 4.00 & 3.2000 & .40825 \\
\hline item 20 & 29 & 2.00 & 4.00 & 2.8200 & .37417 \\
\hline item 21 & 29 & 3.00 & 4.00 & 3.5000 & .50000 \\
\hline item 22 & 29 & 3.00 & 4.00 & 3.4400 & .50662 \\
\hline item 23 & 29 & 3.00 & 4.00 & 3.4000 & .50000 \\
\hline item 24 & 29 & 3.00 & 4.00 & 3.4000 & .50000 \\
\hline item 25 & 29 & 2.00 & 4.00 & 2.8400 & .40825 \\
\hline item 26 & 29 & 3.00 & 4.00 & 3.3600 & .48990 \\
\hline Valid N (listy & 29 & & & & \\
\hline
\end{tabular}

Based on the results of the research, the performance of construction companies in the Public Works and Spatial Planning Office in the city of Banjarmasin has obtained a mean value between 2.80 for item 7 and 3.70 for item 1 . It indicated that the performance of the construction companies was at the level of "sufficiently satisfied" and "satisfied" when implementing a project. In the same context, a study has resulted that there are some components that affect construction's performance, namely human resource, economic, management [10].

The results of this study also expressed that the performance of construction companies in the city of Banjarmasin was "quite satisfied" to "satisfied" (range 2,800-3.70) with a modus 3. This result was obtained from a calculation on respondents' answer in the distributed questionnaire. Based on an ordinal scale as a measurement scale that can be used to state rankings among levels, and has a higher level than the nominal scale, because it did not only clarify categories, but also rankings, some items that have already reached the highest mean value was item 1 with a value of 3.70 and item 2 with a value of 3.68 .

Item 1: the fulfillment in completing project functions.

The performance indicator of item 1 was the fulfillment of job function. A facility for work project activities is carried out based on the basic function of the facility. It indicates the role of the construction company (contractor) as a project organizer. In this study, the construction companies in Banjarmasin City Public Works and Spatial Planning Agency as customers, have implemented these performance indicators well and properly. It was proven from the level of satisfaction of respondents (customers) towards contractors with the mean value 3.70 at the level of satisfaction.

Item 2: the scope of work is in accordance with the project contract documents.

In this item, the performance indicator was how the scope of work could be in accordance with contract documents that have been agreed. A contract was a legal agreement between project giver and project recipient, where the project giver was the project owner and the project recipient was the contractor and construction supervisor. A work contract will define the rights, responsibilities and obligations of each party involved in the implementation of a project both from the technical aspects of the project and the administrative aspects in it.

The scope of work (project) carried out in accordance with the contract documents resulted in the task giver has become more satisfied with performance, because by achieving the level of satisfaction, prospective orders will arise from customers. It means that this way influences the emergence of loyal customers. This evidence is the same as construction company at the Department of Public Works and Spatial Planning Banjarmasin with the level of respondent satisfaction (satisfied).

The results of this study also illustrated that there were twenty variables of construction company performance that have satisfied customers. It could be seen from the mean value and in its handling to maintain performance. The variables were the fulfillment of job functions (Y1), scope of work on contract documents (Y2), quality of work on technical specifications (Y3), neatness (aesthetics) of the final work (Y4), realistic work plans (scheduling) ( Y5), easiness of service (cooperative) (Y8), problems handling (cost, quality, time, conflict, etc) at work (Y9), shop drawing submitted before construction (Y10), conformity of project with an actual condition in the field (Y11), accuracy in selecting suppliers and sub-contractors (Y12), swiftness to handle problems (cost, quality, time, conflict, etc) in the field (Y13), manager's ability to communicate verbally and in written (Y16), informing a possible risk during construction (Y17), integrated communication between contractor, sub-contractor, and supplier (Y18), security handling and socialization in the field (Y19), a complete organization structure of project's executives (Y21), a competent and qualified human resource (Y22), concern on environmental problems during construction (Y23), accuracy of construction working method (Y24), and monitoring and controlling of project that were regularly carried out (Y26).

Furthermore, there were six variables of construction company performance that could still be improved to better satisfy customers. These variables were timeliness of project 
completion (Y6), routine and orderly administration (Y7), speed in responding to project owner requests (Y14), occupational safety and health (K3), systems on construction (Y15), minimum re-work (repair), rework during project implementation (Y20), and cleanliness during construction (Y25).

\subsection{Analysis of correlation between contractor qualification and project work performance}

With an ordinal regression method, the relationship between the qualification of the contractor and work performance of the contractor was carried out by a partial correlation analysis, and assisted by using the Statistical Product and Service Solution (SPSS) program, so that qualification was an independent variable $(\mathrm{X})$, while job performance was dependent variable (Y).

The qualification indicators $(\mathrm{X})$ were: PJBU (X1), PJTBU (X2), certificate for workforce expertise (X3), number of workers (X4), origin of workforce (X5), workforce status (X6), value of work package (X7), total of net wealth (X8), origin of venture capital (X9), number of work packages that have been taken (X10), service users (X11), length of experience in the company (X12), location of work (X13), sub-fields that were frequently worked on (X14), the auction system that was often followed (X15), scope of the procurement area (X16), status of equipment (X17), number of equipment (X18), and age/condition of tools (X19).

Meanwhile, performance indicators (Y) consisted of product and service. By understanding the previous indicators, an analysis was then carried out and resulted in a correlation value for each qualification. The results of the correlation analysis between $\mathrm{X}$ and $\mathrm{Y}$ on contractors $\mathrm{K} 1, \mathrm{~K} 2$ and $\mathrm{K} 3$ are highlighted in the following reports.

3.4 Correlation of the $k 1$ small qualification of construction organizer business enterprise service and performance of $k 1$ construction service company

The analysis on the correlation of the qualification of construction organizer business enterprise service and performance of KI small construction Service Company against the performance of KI small construction Service Company resulted the following data.

Based on previous tables, the result of the Partial Correlation on K1 Small Construction Business Enterprise Service Organizer towards work satisfaction has resulted that there was a positive and significant correlation among factors. Besides, there was also an increase of coefficient value after the variable control of $\mathrm{Y}$ product and $\mathrm{Y}$ service were included in analysis.

Table 5. The result of analysis on the partial correlation on $\mathrm{K} 1$ small construction business enterprise service organizer towards satisfaction of $Y$ product

\begin{tabular}{|c|c|c|c|c|c|c|c|}
\hline \multicolumn{8}{|c|}{ Correlations } \\
\hline \multicolumn{3}{|c|}{ Control Variables } & \multirow{2}{*}{$\frac{\text { Faltoxl }}{1,000}$} & Faktog & \multicolumn{3}{|c|}{ Faktorl1 Faktorl2 YProdik } \\
\hline -none' & Faltorl & Corralation & & ,188 &, 187 &, 143 &, 126 \\
\hline & & $\begin{array}{l}\text { Significance } \\
\text { (2-tailed) }\end{array}$ & - &, 030 &, 040 &, 041 &, 031 \\
\hline & & df & 0 & 11 & 11 & 11 & 11 \\
\hline & Faltore & Corralation &, 188 & 1,000 & 1,000 &, 632 & 299 \\
\hline & & $\begin{array}{l}\text { Significance } \\
\text { (2-tailed) }\end{array}$ &, 030 & . &, 000 &, 020 &, 020 \\
\hline & & $d f$ & 11 & 0 & 11 & 11 & 11 \\
\hline & Faitorl1 & Correlation &, 187 & 1,000 & 1,000 &, 632 & 299 \\
\hline & & $\begin{array}{l}\text { Significance } \\
\text { (2-tsiled) }\end{array}$ &, 040 &, 000 & . &, 020 &, 020 \\
\hline & & df & 11 & 11 & 0 & 11 & 11 \\
\hline & Faltor12 & Correlation &, 143 & ,632 &, 632 & 1,000 & 250 \\
\hline & & $\begin{array}{l}\text { Significance } \\
\text { (2-tailed) }\end{array}$ &, 041 &, 020 &, 020 & . &, 020 \\
\hline & & df & 11 & 11 & 11 & 0 & 11 \\
\hline & YProduk: & Corralation &, 126 &, 299 & 299 &, 250 & 1,000 \\
\hline & & $\begin{array}{l}\text { Significance } \\
\text { (2-tailed) }\end{array}$ &, 031 &, 020 &, 020 &, 020 & . \\
\hline & & $d f$ & 11 & 11 & 11 & 11 & 0 \\
\hline \multirow[t]{12}{*}{ YProduk: } & Fabtorl & Correlation & 1,000 &, 238 & 238 & 216 & \\
\hline & & $\begin{array}{l}\text { Significance } \\
\text { (2-teiled) }\end{array}$ & - &, 006 &, 004 &, 020 & \\
\hline & & df & 0 & 10 & 10 & 10 & \\
\hline & Faltore & Comelation &, 238 & 1,000 & 1,000 &, 765 & \\
\hline & & $\begin{array}{l}\text { Significance } \\
\text { (2-tsiled) }\end{array}$ &, 006 & . &, 000 &, 004 & \\
\hline & & $d f$ & 10 & 0 & 10 & 10 & \\
\hline & Faltorl1 & Correlation &, 238 & 1,000 & 1,000 &, 765 & \\
\hline & & $\begin{array}{l}\text { Significance } \\
\text { (2-tailed) }\end{array}$ &, 004 &, 000 & . &, 004 & \\
\hline & & $d f$ & 10 & 10 & 0 & 10 & \\
\hline & Faltor12 & Corralation &, 216 &, 765 &, 765 & 1,000 & \\
\hline & & $\begin{array}{l}\text { Significance } \\
\text { (2-tsiled) }\end{array}$ &, 020 &, 004 &, 004 & . & \\
\hline & & df & 10 & 10 & 10 & 0 & \\
\hline
\end{tabular}


Table 6. The Result of analysis on the partial correlation on $\mathrm{K} 1$ small construction business enterprise service organizer towards satisfaction of Y service

\begin{tabular}{|c|c|c|c|c|c|c|c|}
\hline \multicolumn{8}{|c|}{ Correlations } \\
\hline Control & Variables & & Faltorl & Faktor8 & Falitor 12 & Filitor 18 & YServis \\
\hline \multirow[t]{15}{*}{$-n o n e^{2}$} & \multirow[t]{3}{*}{ Falktorl } & \multirow{3}{*}{$\begin{array}{l}\text { Correlation } \\
\text { Significane } \\
\text { (2-tailed) } \\
\text { df }\end{array}$} & 1,000 &, 022 &, 143 &, 217 &, 013 \\
\hline & & & - &, 042 &, 041 &, 047 &, 000 \\
\hline & & & 0 & 11 & 11 & 11 & 11 \\
\hline & \multirow[t]{3}{*}{ Faktors } & \multirow{3}{*}{$\begin{array}{l}\text { Correlation } \\
\text { Significano } \\
\text { (2-tailed) } \\
\text { df }\end{array}$} &, 022 & 1,000 & ,145 & ,537 & ,018 \\
\hline & & &, 042 & . &, 037 &, 049 &, 004 \\
\hline & & & 11 & 0 & 11 & 11 & 11 \\
\hline & \multirow[t]{3}{*}{ Faltor 12} & \multirow{2}{*}{$\begin{array}{l}\text { Correlstion } \\
\text { Significano }\end{array}$} &, 143 &, 145 & 1,000 &, 231 &, 083 \\
\hline & & &, 041 &, 037 & . &, 048 &, 000 \\
\hline & & df & 11 & 11 & 0 & 11 & 11 \\
\hline & \multirow[t]{3}{*}{ Faltor 18} & Correlation &, 217 &, 537 & ,231 & 1,000 &, 293 \\
\hline & & $\begin{array}{l}\text { Significane } \\
\text { (2-tailed) }\end{array}$ &, 047 &, 049 &, 048 & - &, 032 \\
\hline & & $\mathrm{df}$ & 11 & 11 & 11 & 0 & 11 \\
\hline & \multirow[t]{3}{*}{ YServis } & \multirow{3}{*}{$\begin{array}{l}\text { Correlation } \\
\text { Significano } \\
\text { (2-tailed) } \\
\text { df }\end{array}$} &, 013 &, 018 & ,083 &, 293 & 1,000 \\
\hline & & &, 000 &, 004 &, 000 &, 032 & . \\
\hline & & & 11 & 11 & 11 & 11 & 0 \\
\hline \multirow[t]{12}{*}{ YServis } & \multirow[t]{3}{*}{ Faltor1 } & \multirow{2}{*}{$\begin{array}{l}\text { Correlation } \\
\text { Significance }\end{array}$} & 1,000 &, 023 &, 145 & 231 & \\
\hline & & & - &, 045 &, 004 &, 001 & \\
\hline & & df & 0 & 10 & 10 & 10 & \\
\hline & \multirow[t]{3}{*}{ Faktor8 } & Correlation & ,023 & 1,000 &, 144 &, 556 & \\
\hline & & $\begin{array}{l}\text { Significanos } \\
\text { (2-tailed) }\end{array}$ &, 045 & - &, 006 &, 041 & \\
\hline & & $\mathrm{df}$ & 10 & 0 & 10 & 10 & \\
\hline & \multirow[t]{3}{*}{ Falktor 12} & Correlation & , 145 &, 144 & 1,000 &, 217 & \\
\hline & & $\begin{array}{l}\text { Significance } \\
\text { (2-tailed) }\end{array}$ &, 004 &, 006 & . &, 040 & \\
\hline & & df & 10 & 10 & 0 & 10 & \\
\hline & \multirow[t]{3}{*}{ Faltor18 } & Correlation &, 231 &, 556 &, 217 & 1,000 & \\
\hline & & $\begin{array}{l}\text { Significanes } \\
\text { (2-tsiled) }\end{array}$ &, 001 &, 041 &, 040 & . & \\
\hline & & $\mathrm{df}$ & 10 & 10 & 10 & 0 & \\
\hline
\end{tabular}

Table 7. The result of analysis on the partial correlation of the $\mathrm{K} 2$ small qualification of construction organizer business enterprise service towards satisfaction of Y product

\begin{tabular}{|c|c|c|c|c|c|c|c|}
\hline \multicolumn{8}{|c|}{ Correlations } \\
\hline \multicolumn{3}{|c|}{ Control Verisbles } & \multicolumn{2}{|c|}{ Faltorl Faktoss } & \multirow{2}{*}{$\frac{\text { Faktors }}{187}$} & \multicolumn{2}{|c|}{ Faltorl2 YProdi } \\
\hline$-n o b e^{2}$ & Faitorl & Correlation & 1,000 &, 188 & &, 143 &, 126 \\
\hline & & $\begin{array}{l}\text { Significance } \\
\text { (2-tailed) }\end{array}$ & - &, 026 &, 042 &, 041 &, 031 \\
\hline & & df & 0 & 11 & 11 & 11 & 11 \\
\hline & Faitor8 & Corralstion &, 188 & 1,000 & 1,000 &, 632 & 399 \\
\hline & & $\begin{array}{l}\text { Significance } \\
\text { (2-tsiled) }\end{array}$ &, 026 & . &, 000 &, 030 &, 020 \\
\hline & & $d f$ & 11 & 0 & 11 & 11 & 11 \\
\hline & Faitore & Correlation &, 187 & 1,000 & 1,000 &, 532 &, 299 \\
\hline & & $\begin{array}{l}\text { Significance } \\
\text { (2-tsiled) }\end{array}$ &, 042 &, 000 & . &, 020 &, 020 \\
\hline & & df & 11 & 11 & 0 & 11 & 11 \\
\hline & Faltor12 & Correlation &, 126 &, 632 & ,532 & 1,000 &, 150 \\
\hline & & $\begin{array}{l}\text { Significsnce } \\
\text { (2-tailed) }\end{array}$ & 031 &, 030 &, 020 & - &, 020 \\
\hline & & df & 11 & 11 & 11 & 0 & 11 \\
\hline & Yprodul: & Conelation &, 126 &, 399 &, 299 & , 150 & 1,000 \\
\hline & & $\begin{array}{l}\text { Significance } \\
\text { (2-tsiled) }\end{array}$ & 031 &, 020 &, 020 &, 020 & \\
\hline & & df & 11 & 11 & 11 & 11 & 0 \\
\hline \multirow[t]{12}{*}{ YProdul: } & Faltor 1 & Correlation & 1,000 &, 238 &, 238 &, 216 & \\
\hline & & & - &, 006 &, 004 &, 020 & \\
\hline & & $d f$ & 0 & 10 & 10 & 10 & \\
\hline & Faltor8 & Correlation &, 238 & 1,000 & 1,000 &, 965 & \\
\hline & & $\begin{array}{l}\text { Significance } \\
\text { (2-tsiled) }\end{array}$ &, 006 & . &, 000 &, 004 & \\
\hline & & df & 10 & 0 & 10 & 10 & \\
\hline & Faltors & Correlation &, 238 & 1,000 & 1,000 &, 865 & \\
\hline & & $\begin{array}{l}\text { Significance } \\
\text { (2-tailed) }\end{array}$ &, 004 &, 000 & . &, 004 & \\
\hline & & $d f$ & 10 & 10 & 0 & 10 & \\
\hline & Faltor12 & Correlation &, 216 & ,965 &, 865 & 1,000 & \\
\hline & & $\begin{array}{l}\text { Significance } \\
\text { (2-tsiled) }\end{array}$ &, 020 &, 004 &, 004 & 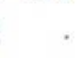 & \\
\hline & & df & 10 & 10 & 10 & 0 & \\
\hline
\end{tabular}


Table 8. The result of analysis on the partial correlation of the K2 small qualification of construction organizer business enterprise service towards satisfaction of Y service

\begin{tabular}{|c|c|c|c|c|c|c|c|}
\hline \multicolumn{8}{|c|}{ Correlations } \\
\hline \multirow{16}{*}{-nonet } & Variables & & Faltor1 & Falitor3 & Faitores & Falktor17 & Yservis \\
\hline & \multirow[t]{3}{*}{ Faltorl } & \multirow{3}{*}{$\begin{array}{l}\text { Correlation } \\
\text { Significance } \\
\text { (2-triled) } \\
\text { df }\end{array}$} & 1,000 &, 522 & .443 &, 517 &, 513 \\
\hline & & & - &, 032 &, 021 &, 007 &, 000 \\
\hline & & & 0 & 11 & 11 & 11 & 11 \\
\hline & \multirow[t]{3}{*}{ Faltor 3} & \multirow{3}{*}{$\begin{array}{l}\text { Correlation } \\
\text { Significanor } \\
\text { (2-tailed) } \\
\text { df }\end{array}$} &, 522 & 1,000 & ,545 &, 557 &, 618 \\
\hline & & & ,032 & . &, 037 & , 009 &, 004 \\
\hline & & & 11 & 0 & 11 & 11 & 11 \\
\hline & \multirow[t]{3}{*}{ Faltors } & \multirow{2}{*}{$\begin{array}{l}\text { Correlation } \\
\text { Significano }\end{array}$} & , 443 & ,545 & 1,000 & ,531 & ,783 \\
\hline & & &, 021 &, 037 & - &, 004 &, 000 \\
\hline & & df & 11 & 11 & 0 & 11 & 11 \\
\hline & \multirow[t]{3}{*}{ Faltor 1 ? } & Correlation & ,517 & ,557 & ,531 & 1,000 & ,593 \\
\hline & & Significander &,$\infty$ &, 009 & ,004 & - & ,032 \\
\hline & & df & 11 & 11 & 11 & 0 & 11 \\
\hline & \multirow[t]{3}{*}{ Yservis } & \multirow{3}{*}{$\begin{array}{l}\text { Correlation } \\
\text { Significanos } \\
\text { (2-tailed) } \\
\text { df }\end{array}$} &, 513 & ,618 &, 783 & ,593 & 1,000 \\
\hline & & & ,000 & , 004 &, 000 &, 032 & . \\
\hline & & & 11 & 11 & 11 & 11 & 0 \\
\hline \multirow[t]{12}{*}{ YServis } & Faltor l & Correlation & 1,000 & ,623 & ,534 & ,631 & \\
\hline & & $\begin{array}{l}\text { Significanas } \\
\text { (2-tailed) }\end{array}$ & - &, 032 &, 004 &, 001 & \\
\hline & & df & 0 & 10 & 10 & 10 & \\
\hline & \multirow[t]{3}{*}{ Faltor 3} & Correlation & ,623 & 1,000 & ,344 & ,556 & \\
\hline & & $\begin{array}{l}\text { Significanos } \\
\text { (2-tailed) }\end{array}$ &, 032 & - &, 006 &, 041 & \\
\hline & & $d f$ & 10 & 0 & 10 & 10 & \\
\hline & \multirow[t]{6}{*}{ Faltors } & Correlation & ,534 & ,344 & 1,000 & , 417 & \\
\hline & & $\begin{array}{l}\text { Significane } \\
\text { (2-teiled) }\end{array}$ &, 004 &, 006 & . &, 040 & \\
\hline & & df & 10 & 10 & 0 & 10 & \\
\hline & & Correlation & ,631 & ,556 &, 417 & 1,000 & \\
\hline & & $\begin{array}{l}\text { Significance } \\
\text { (2-tailed) }\end{array}$ &, 001 & ,041 &, 040 & - & \\
\hline & & df & 10 & 10 & 10 & 0 & \\
\hline
\end{tabular}

Table 9. The result of analysis on the partial correlation of the $\mathrm{K} 3$ small qualification of construction organizer business enterprise service towards satisfaction of Y product

\begin{tabular}{|c|c|c|c|c|c|c|c|}
\hline \multicolumn{8}{|c|}{ Comelations } \\
\hline \multicolumn{3}{|c|}{ Control Varisbles } & \multicolumn{2}{|c|}{ Faktoxl Faktos } & \multicolumn{3}{|c|}{ Faktors Faktorl? YProdu } \\
\hline \multirow[t]{15}{*}{$-100 \mathrm{~A}^{2}$} & Fabtorl & Comelation & 1,000 &, 588 &, 687 &, 543 &, 626 \\
\hline & & $\begin{array}{l}\text { Significance } \\
\text { (2-tsiled) }\end{array}$ & . &, 030 &, 002 &, 031 &, 031 \\
\hline & & $d f$ & 0 & 11 & 11 & 11 & 11 \\
\hline & Faltori & Correlation &, 588 & 1,000 & 1,000 &, 632 &, 599 \\
\hline & & $\begin{array}{l}\text { Significance } \\
\text { (2-tsiled) }\end{array}$ &, 030 & . &, 000 &, 030 &, 020 \\
\hline & & $d f$ & 11 & 0 & 11 & 11 & 11 \\
\hline & Faltors & Comelation &, 687 & 1,000 & 1,000 &, 532 &, 699 \\
\hline & & $\begin{array}{l}\text { Significance } \\
\text { (2-tailed) }\end{array}$ &, 002 &, 000 & . &, 030 &, 020 \\
\hline & & $d f$ & 11 & 11 & 0 & 11 & 11 \\
\hline & Faktor 17 & Comelation &, 543 &, 632 &, 532 & 1,000 &, 750 \\
\hline & & $\begin{array}{l}\text { Significance } \\
\text { (2-tsiled) }\end{array}$ &, 031 &, 030 &, 020 & ${ }^{\circ}$ &, 020 \\
\hline & & df & 11 & 11 & 11 & 0 & 11 \\
\hline & Yprodul: & Correlation &, 626 &, 599 &, 699 &, 750 & 1,000 \\
\hline & & $\begin{array}{l}\text { Significance } \\
\text { (2-tailed) }\end{array}$ &, 031 &, 020 &, 020 &, 020 & \\
\hline & & df & 11 & 11 & 11 & 11 & 0 \\
\hline \multirow[t]{12}{*}{ YProduk: } & Faltorl & Comelation & 1,000 &, 738 & ,838 &, 566 & \\
\hline & & $\begin{array}{l}\text { Significance } \\
\text { (2-tailed) }\end{array}$ & . &, 006 &, 004 &, 020 & \\
\hline & & $d f$ & 0 & 10 & 10 & 10 & \\
\hline & Faltor3 & Correlation &, 738 & 1,000 & 1,000 &, 965 & \\
\hline & & $\begin{array}{l}\text { Significance } \\
\text { (2-tailed) }\end{array}$ &, 006 & &, 000 &, 004 & \\
\hline & & $d f$ & 10 & 0 & 10 & 10 & \\
\hline & Faltors & Correlation &, 838 & 1,000 & 1,000 &, 865 & \\
\hline & & $\begin{array}{l}\text { Significance } \\
\text { (2-tailed) }\end{array}$ &, 004 &, 000 & . &, 004 & \\
\hline & & $d f$ & 10 & 10 & 0 & 10 & \\
\hline & Faltor 17 & Correlation &, 566 &, 965 &, 865 & 1,000 & \\
\hline & & $\begin{array}{l}\text { Significance } \\
\text { (2-tailed) }\end{array}$ &, 020 &, 004 &, 004 & - & \\
\hline & & $d f$ & 10 & 10 & 10 & 0 & \\
\hline
\end{tabular}


Table 10. The result of analysis on the partial correlation of the $\mathrm{K} 3$ small qualification of construction organizer business enterprise service towards satisfaction of $\mathrm{Y}$ service

\begin{tabular}{|c|c|c|c|c|c|c|c|}
\hline \multicolumn{8}{|c|}{ Correlations } \\
\hline \multicolumn{3}{|c|}{ Control Variables } & Faittor1 & Falktor3 & Faltory & Falktor 17 & Ysenvis \\
\hline \multirow[t]{15}{*}{$-n 0 a^{2}$} & \multirow[t]{3}{*}{ Faltor1 } & \multirow{3}{*}{$\begin{array}{l}\text { Correlation } \\
\text { Significane } \\
\text { (2-tailed) } \\
\text { df }\end{array}$} & 1,000 &, 522 &, 443 &, 517 &, 513 \\
\hline & & & 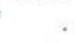 &, 032 &, 021 &, 007 &, 000 \\
\hline & & & 0 & 11 & 11 & 11 & 11 \\
\hline & \multirow[t]{3}{*}{ Faltor 3} & \multirow{3}{*}{$\begin{array}{l}\text { Correlation } \\
\text { Significanor } \\
\text { (2-tailed) } \\
\text { df }\end{array}$} &, 522 & 1,000 & ,545 &, 557 & ,618 \\
\hline & & &, 032 & . &, 037 &, 009 &, 004 \\
\hline & & & 11 & 0 & 11 & 11 & 11 \\
\hline & \multirow[t]{3}{*}{ Faltors } & \multirow{3}{*}{$\begin{array}{l}\text { Correlation } \\
\text { Significano } \\
\text { (2-tailed) } \\
\text { df }\end{array}$} & , 443 &, 545 & 1,000 &, 531 &, 783 \\
\hline & & &, 021 &, 037 & . &, 004 &, 000 \\
\hline & & & 11 & 11 & 0 & 11 & 11 \\
\hline & \multirow[t]{3}{*}{ Faltor 17} & Correlation &, 517 &, 557 &, 531 & 1,000 & ,593 \\
\hline & & \multirow{2}{*}{$\begin{array}{l}\text { Significance } \\
\text { (2-tailed) } \\
\text { df }\end{array}$} &,$\infty 0$ &, 009 &, 004 & - &, 032 \\
\hline & & & 11 & 11 & 11 & 0 & 11 \\
\hline & \multirow[t]{3}{*}{ Yservis } & \multirow{3}{*}{$\begin{array}{l}\text { Correlation } \\
\text { Significano } \\
\text { (2-tailed) } \\
\text { df }\end{array}$} & ,513 &, 618 & ,783 & ,593 & 1,000 \\
\hline & & &, 000 & , 004 &, 000 &, 032 & . \\
\hline & & & 11 & 11 & 11 & 11 & 0 \\
\hline \multirow[t]{12}{*}{ YServis } & Faltorl & Correlation & 1,000 & ,623 &, 534 & 631 & \\
\hline & & $\begin{array}{l}\text { Significande } \\
\text { (2-tsiled) }\end{array}$ & + &, 032 &, 004 &, 001 & \\
\hline & & $\mathrm{df}$ & 0 & 10 & 10 & 10 & \\
\hline & \multirow[t]{3}{*}{ Faltor 3} & Correlation &, 623 & 1,000 &, 344 & ,556 & \\
\hline & & $\begin{array}{l}\text { Significanor } \\
\text { (2-tailed) }\end{array}$ &, 032 & . &, 006 & ,041 & \\
\hline & & $\mathrm{df}$ & 10 & 0 & 10 & 10 & \\
\hline & \multirow[t]{6}{*}{ Faltors } & Correlation & ,534 & ,344 & 1,000 & , 417 & \\
\hline & & $\begin{array}{l}\text { Significane } \\
\text { (2-tailed) }\end{array}$ &, 004 &, 006 & * &, 040 & \\
\hline & & df & 10 & 10 & 0 & 10 & \\
\hline & & Correlation & 631 & ,556 & ,417 & 1,000 & \\
\hline & & $\begin{array}{l}\text { Significanos } \\
\text { (2-tailed) }\end{array}$ &, 001 &, 041 &, 040 & - & \\
\hline & & df & 10 & 10 & 10 & 0 & \\
\hline
\end{tabular}

Based on Table 5 and Table 6, it was obtained that there was a positive and significant correlation among factors. There was also an increase of correlation's coefficient value after variable control Y Product and Y service were included in the analysis.

3.5 Correlation of the $\mathrm{K} 2$ Small qualification of construction organizer business enterprise service and performance of $K 2$ construction service company

The result of analysis on the correlation of the K2 small qualification of construction organizer business enterprise service and performance of K2 construction Service Company can be seen in the Tables 7 and 8 above.

3.6 Correlation of the $\mathrm{K} 3$ small qualification of construction organizer business enterprise service and performance of $\mathrm{K} 3$ construction service company

The result of the analysis on correlation of the $\mathrm{K} 3$ small qualification of construction organizer business enterprise service and performance of K3 small construction Service Company can be described in Tables 9 and 10 .

Both tables indicated that there was a positive and significant correlation among factors. Besides, there was also an increase of correlation's coefficient value after variable control Y Product and Y Service were included in the analysis.

\section{DISCUSSION}

\subsection{A draft of strategy for performance}

Based on the results of this study, there are several factors that are considered negative (not good), so that it affects the achievement of good project performance. The timeliness of project completion, a routine and orderly administration, quick responding to requests from project owners, occupational safety and health (K3) systems during construction, minimum repair/re-work during project implementation and cleanliness in the field during the construction period are incapable to satisfy customers. This has become a serious concern for the owner and organizer of a project. Moreover, apart from unsatisfied project, lateness of project completion also becomes a problem in project construction [11]

Some improvement efforts have been carried out by Banjarmasin Public Works and Spatial Planning Office (PUPR) as well as other stakeholders in the sector of construction services in Banjarmasin city and generally for South Kalimantan Province through an obvious regulation in accordance with the Construction Services Law and applicable Regulation. The role of founding for small qualified contractors that becomes the responsibility of local government through the Regional Construction Services Sector is the spearhead of regional business and professional association, such as providing training, workshop and seminar for experts and skilled workers. The availability of knowledge sources and improved implementation method will be an innovation for the development of regional construction services.

For the contractor, some qualifications that have become small strategies formulated and implemented to improve performance, namely (a) fostering good relations with government; (b) maximizing the use of existing human resources; (c) increasing the trust of the owners through increased performance; (d) utilizing existing resources in the company; (e) developing any cooperation with government to improve the quality of personnel through education and training, course program and workshop; (f) expanding any 
network of cooperation especially related to parties; (g) increasing teamwork in company organization; (h) maximizing the use of local resources in company environment; and (i) tightening cash-flow to reduce dependence on credit providers (e.g. bank).

\section{CONCLUSION}

This study has indicated that the qualification of contractors who handle construction projects in Banjarmasin City is a small qualification with sub-qualifications as K1, K2 and K3. In the legal aspect, all contractors who handle projects at the Banjarmasin Public Works and Spatial Planning Office (PUPR) already have a Business Entity Certificate (SBU) which is issued by the Construction Services Development Agency which displays and presents the identity of the construction service company. This evidence is in accordance with the qualification requirements for government procurement of goods/services according to Presidential Decree No. 18 of 2018 that construction service business agencies must have a clear identity.

On the other hand, the factors that influence the performance of construction projects in Banjarmasin are the fulfillment factor of job function and scope of work based on the contract document. Therefore, the relationship between small contractors with the performance of construction project work in Banjarmasin is acknowledged and influenced by a person in-charge of the business agencies which has a positive and significant relationship among factors.

As implication, there are some considerable suggestions resulted from this study, namely:

1. Further research can also be carried out by evaluating the performance of medium qualification companies, namely M1 and M2.

2. The construction customer should be more careful in viewing the performance of the construction company in order that work items can be completed properly and on time.

3. There should be any effort to develop small qualified contractors by the government of Banjarmasin to transfer knowledge, management, and technology to advance and improve the capacity of small qualified contractors.

4. The variable of project management performance evaluation can be taken into consideration by construction companies as an effort to improve services and products for customers.

\section{ACKNOWLEDGMENT}

The author would like to deliver his gratitude to the Banjarmasin City Public Works and Spatial Planning Agency for availability of time for interview and observation. The author also would like to declare that this study is not under any consideration of any funding sources.

\section{REFERENCES}

[1] Muzaidi, I., Anggarini E., Prayugo, H.M. (2018). Studi kasus pencemaran air sungai teluk dalam Banjarmasin akibat limbah domestic. Media Teknik Sipil, 16(2): 108114.

[2] Hardianto, R., Muzawi, R. (2016). Sistem pendukung keputusan untuk menentukan pemenang tendor kontraktor menggunakan metode AHP (Studi kasus di Dinas Pekerjaan Umum kabupaten Agam). Jurnal Inovtek Polbeng - Seri Informatika, 1(2): 169-176. https://doi.org/10.35314/isi.v1i2.136

[3] Silalahi, U. (2015). Metode Penelitian Sosial Kuantitatif. PT. Refika Aditama, Bandung.

[4] Collins, W., Parrish, K., Gibson Jr, G.E. (2017). Defining and understanding "small projects" in the industrial construction sector. Procedia engineering, 196: 315-322. https://doi.org/10.1016/j.proeng.2017.07.205

[5] Kaplan, R.S., Norton, D.P. (2000). Balanced Scorecard: Menerjemahkan Strategi Menjadi Aksi, Erlangga, Jakarta.

[6] Nazir. (2014). Metode Penelitian, Ghalia Indonesia, Bogor.

[7] Asnudin, A. (2008). Potensi bisnis usaha jasa konstruksi di Indonesia. SMARTek, 6(4): 228-240.

[8] Assa, J.I., Mandagi, R.J.M., Tjakra, J., Sibi, M. (2014). Kajian peranan pengelola proyek dalam menyelenggarakan proyek pada tahap pelaksanaan. Jurnal Sipil Statik, 2(2): 94-106.

[9] Saefudin, A.H., Mudianto, A., Wiranto, P. (2016). Kajian penggunaan alat-alat berat pada proyek pembangunan jalan raya ditinjau dari aspek teknis dan ekonomi (Studi kasus proyek pembangunan jalan tol BOCIMI). Jurnal Online Mahasiswa, 1(1): 1-14.

[10] Noumeiry, N. (2017). Kajian faktor-faktor yang berpengaruh terhadap kinerja proyek konstruksi (Studi kasus proyek gedung di Kota Samarinda). Jurnal Teknologi Berkelanjutan, 6(1): 110-117.

[11] Mangare. J.B., Pratasis, P.A.K. (2016). Faktor-faktor penyebab keterlambatan pada proyek konstruksi dan alternatif penyelesaiannya (Studi kasus: di Manado Town Square III). Jurnal Sipil Statik, 4(11): 657-664.

\section{NOMENCLATURE}

$\begin{array}{ll}\text { K3 } & \text { Health and work safety } \\ \text { M1 } & \text { Medium 1 } \\ \text { M2 } & \text { Medium 2 }\end{array}$

